\title{
Design and Analysis of the E-Journal Repository for Final Projects and Student Practices in the D3 Computer Engineering
}

\author{
Ida Afriliana ${ }^{1 *}$, M.Bahar $^{1}$, Abdul Basit $^{1}$ \\ ${ }^{1}$ Computer Engineering, Politeknik Harapan Bersama Indonesia. \\ * Corresponding author: \\ Email: idaafriharahap@gmail.com
}

\begin{abstract}
.
Higher education institutions are the main institutions in creating young people who can be ready to enter the world of work and industry, and one of the educational programs that take part in vocational education. Vocational education is higher education that is directed at focusing certain applied skills. Polytechnic of Harapan Bersama is one of the vocational education institutions that provides Human Resources (HR) to become the younger generation as practitioners in industry, companies, or other stoke holders. In the D3 Computer Engineering Study Program, each batch can graduate approximately 300 graduates, where each graduate will produce one scientific work from the final project research conducted. Likewise, with students who do practical work (KP), every student who does KP will produce scientific papers. But all the results of this scientific work, namely the research report of the Final Project and the Job Training Report are still being submitted to the Study Program in one compact disk (CD). This turned out to be a problem for the Study Program because from each batch, around 300 compact disks (CDs) were collected from the results of scientific work from the practical work and 300 compact disks (CDs) from the final project research outputs. Physical data in the form of a compact disk (CD) requires a large space for its placement. Meanwhile, the condition of the D3 Computer Engineering study program room makes it impossible to place the physical form. And along with technological developments, this physical form can be replaced by soft files in the form of e-journals or e-reports. This needs to be done in line with the paradigm shift from conventional libraries to e-libraries. With the existence of SIPESTA or the information system for the completion of this Final Project, the results of writing scientific papers are uploaded and become a digital trace of all scientific papers that have been carried out by all D3 Computer Engineering students. And so if this data is needed it will be easy to find because the database has been well managed.
\end{abstract}

Keywords: Information system, SIPESTA, e-repository,

\section{INTRODUCTION}

Higher education institutions are the main institutions in creating young people who can be ready to enter the world of work and industry and one of the educational programs that take part in vocational education. Vocational education is higher education that is directed at mastering certain applied skills. Polytechnic of Harapan Bersama is one of the vocational education institutions that provide Human Resources 
(HR) to become the younger generation as practitioners in industry, companies, or other stoke holders.

The Polytechnic of Harapan Bersama is one of the vocational education institutions that provide Human Resources to become the younger generation as practitioners in industry, companies, or other stakeholders. In 2015 this institution had 7 study programs, including: 1) DIV of Informatics Engineering: 2) DIII Midwifery; 3) DIII Pharmacy; 4) DIII Computer Engineering; 5) DIII Accounting; 6) DIII Mechanical Engineering; 7) DIII Electronics Engineering[1]. But now this institution have 10 study programs.

The Polytechnic of Harapan Bersama is a vocational education located in Tegal City, Central of Java, with total students more than 4000 students and many administration staff and lecturers consisting of various study programs. D3 Computer Engineering Study Program is one of the study programs at the Polytechnic of Harapan Bersama where this study program has nearly 1000 students and it has more than 50 lecturers.

In the D3 Computer Engineering Study Program, each batch can graduate approximately 300 graduates, where each graduate will produce one scientific work from the final project research conducted. Likewise, with students who do practical work (KP), every student who does KP will produce scientific papers. But all the results of this scientific work, namely the research report of the Final Project, article, and the Job Training Report are still being submitted to the Study Program in one compact disk (CD). This turned out to be a problem for the Study Program because, from each batch, around 300 compact disks (CDs) were collected from the results of scientific work from the practical work and 300 compact disks (CDs) from the final project research output. Physical data in the form of a compact disk (CD) requires a large space for its placement. Meanwhile, the condition of the D3 Computer Engineering study program room does not allow the physical form to be placed. And along with technological developments, this physical form can be replaced by soft files in the form of e-journals or e-reports.

A repository is a place for storing and maintaining hundreds of data, applications, or programs in digital format for distribution by computer networks and available which can be accessed from the internet or other media. In the scope of the higher education community, the repository is known as the institutional repository, which has a close relationship with the digital library[2]. This repository is generally needed as an online place to collect, manage, distribute, and preserve scientific works produced by the academic community of these universities. Scientific works produced by the academic community are generally in the form of articles from research journals, either before or after being printed, digital formats of final assignments, theses, theses or even dissertations and may also be digital data collections on academic activities such as administrative documents of the academic community, lecture notes or other lecture material. The results of these scientific works will be reused so that the search for the data can be accessed easily. Research on this 
repository was also conducted by Antonius Rachmat C with the title Research Analysis of the Design and Build System of a Dublin Core Metadata-Based Institution Repository at UKDW Yogyakarta in 2014. Researchers see that UKDW needs a special institutional repository that can manage data from the UKDW academic community outside the thesis. , student theses and dissertations such as posters, songs, films, other public documents, and many others. This system was built at UKDW under the library unit as an online central repository manager[3]. The development of information and communication technology in the form of the internet has shown tremendous influence in every aspect of human life. This has also penetrated the library. As a result, several libraries are gradually being abandoned by their librarians, they prefer the internet to find information rather than come to the library. This can be understood because the internet offers speed and accuracy in searching for information. So that users who have been choosing to use print collections have switched to digital collections[4]. Framing an institutional repository as a service is an important step as it requires library staff to focus outward and make decisions that benefit the individuals and groups they are serving. This is in contrast to concentrating their efforts primarily on the creation of a collection of digital objects. For example, repository staff works to create quality records for their full-text documents, guaranteeing access to these items. However, a repository may also create metadata-only records for any faculty publication they cannot include in their collection, such as works published in journals with restrictive copyright policies[5]. The effectiveness of library collection services is an important element for a library itself because users can get the information needed by utilizing the collections provided by the library. However, a large number of collections in a library cannot be used as the main benchmark for whether or not a library is ideal[6].

This repository can be a solution for the results of scientific work produced by D3 Computer Engineering study program students, where journals and Final Project Reports or Practical Work Reports of D3 Computer Engineering Study Program students can be uploaded in this repository. With this background problem, research was carried out to build an E-Journal repository for Final Projects and Job Training for D3 Computer Engineering Study Program students. With this E-Journal, the repository will be able to accommodate all student scientific works.

The research problem is How to build an e-Journal repository system for Final Projects and Practical Work for D3 Computer Engineering Study Program students. This e-Journal repository is evidence of reporting evidence of the Final Project and practical work that has been done by students so that all reports will be stored and recorded properly. This e-repository will be linked to the D3 Computer Engineering study program website. 
The purpose of this research is to produce an e-Journal repository of scientific papers such as Final Project Reports, Journals, and Job Training Reports for D3 Computer Engineering Study Program students, in this case for Polytechnic of Harapan Bersama.

\section{METHODS}

The analytical system selected to conduct this investigation is based on the suitability for characterizing these problems. The research proposal was developed based on the development of software engineering through several stages, namely direct observation until the product is ready for testing. The model used is the Waterfall Model according to references from Sommerville, 2001.

The first step is Requirements Analysis and Definition, this step is Collecting data needs, namely data on the flow of submission of student final project reports, student practical work and student final project research journals to the D3 Computer Engineering Study Program and the library or some authorized parties, such as final assignment supervisors or practical work.

The next step are System Design, therefore the design is made using the Unified Modeling Language (UML), namely the use case, Activity Diagram, Sequence Diagram, and Class Diagram.

The last steps is Implementation and Unit Testing. In this step is Display design and implementation information system needs to be done in this study during the even semester for students who graduates in 2019/2020.

Getting data that is truly accurate, relevant, valid, and reliable, data collection is carried out by primary data sources from Computer Engineering DIII Study Program, as well as for students and lecturers who teach courses and secondary data sources was taken from books, documentation, and literature. Primary data sources collecting directly from the object of research, either through observation or recording of the object of research, includes observation and interview.

\section{RESULT AND DISCUSSION}

In this research, the e-journal repository design is made according to the needs of the user, D3 Computer Engineering Study Program. This e-journal repository serves as an effort to efficiently manage data on the results of the final Project and practical work of D3 Computer Engineering study program students and data effectiveness if the data will be required for accreditation or the exhibition of graduates results. The result of this e-journal repository design is named SIPESTA or stands for Final Project Completion Information System.

The final project results of the D3 Computer Engineering study program students consist of 3 competencies, namely Hardware, Programming, and Networking. Then there are types of outputs from the student's final assignments, there are A hardware project equipped with website or android, Website-based software or applications, Project in the form of hardware system network or application/software, Report on the results of Scientific Final Project or Job Training and Final Project research journal 
Table 1. Product Classification based on Title category of Final Project

\begin{tabular}{|c|c|c|c|}
\hline $\begin{array}{c}\text { Academic's } \\
\text { year }\end{array}$ & Many Tittles & $\begin{array}{c}\text { Final Project with Robotic } \\
\text { Products / Arduino }\end{array}$ & Percentage \\
\hline $2016 / 2017$ & 421 & 50 & $12 \%$ \\
\hline $2017 / 2018$ & 371 & 292 & $79 \%$ \\
\hline $2018 / 2019$ & 355 & 348 & $98 \%$ \\
\hline $2019 / 2020$ & 108 & 99 & $92 \%$ \\
\hline
\end{tabular}

In table 1, it can be seen that for 4 years, the trend of submitting student Final Project Titles in the form of Hardware Projects which are equipped with website or android based software is $90 \%$, while the Final Project which produces a website or information system network is only around $8 \%-10 \%$.

From each year the collection results in the form of CDs from students can amount to hundreds. Each batch consists of more than 300 students, the minimum CD collected is $100 \mathrm{CDs}$, because if the Hardware project can be done in groups with a maximum of 3 students. It can be calculated from one batch that 100-150 CDs can be collected and it continues to be collected every year, so storage is a problem at this time. With the study program room that does not have a large archive storage warehouse, this storage is scattered in several places so that in the end, when the data is needed, the study program has difficulty finding the physical data.

The data is only student final project data, not to mention the data on practical work reports from $4^{\text {th }}$-semester students, which can reach $300 \mathrm{CDs}$ each year, and each keeping is packed in a CD box.

So in total, each batch can collect a maximum of $500 \mathrm{CD}$ boxes in the study program administration room. So with this e-journal repository, it will erase the CD collection process of each scientific work produced from student practical work and final assignments, and it will be replaced by the process of uploading the scientific work to an information system called SIPESTA.

The situation analysis becomes the reference for this research, so the erepository design is carried out following the guidelines for collecting the Final Project Study Program where students at the time of completing the Final Project must collect several files at SIPESTA, including;1)Final Project Report in pdf format; 2)Final Project Journal Report; 3)Proof of collection of tools from the Hardware Laboratory; 4)Brochures and how to use the resulting hardware tools; 5)Original scan of the ratification and approval sheet; 6) Form for collecting all files that can be printed and used as a condition for obtaining a certificate.

The design used in this application is the Unified Modeling Language (UML). The software used is the Microsoft Windows 7 operating system, the Xampp application program, the MySQL database application program, and PHP as a programming language, the Sublime Text application program. 
Table 2. Actor Identification

\begin{tabular}{|l|l|l|}
\hline No & \multicolumn{1}{|c|}{ Actor } & \multicolumn{1}{|c|}{ Description } \\
\hline 1. & User & $\begin{array}{l}\text { Users here are students registered in the student who } \\
\text { submitted the title of the Final Project and has } \\
\text { finished carrying out the trial. }\end{array}$ \\
\hline 2. & Admin & $\begin{array}{l}\text { Admin is the administrative staff of the study } \\
\text { program whose task is to validate the data uploaded } \\
\text { by students. }\end{array}$ \\
\hline 3 & Superadmin & $\begin{array}{l}\text { Admin is the administrative staff of the study } \\
\text { program whose task is to validate the data uploaded } \\
\text { by students and can manage other actors, namely } \\
\text { students and admins. }\end{array}$ \\
\hline
\end{tabular}

The use case identification can be seen in table 3, where a description of the activities in SIPESTA is described.

Table 3. Description of the actor's activities

\begin{tabular}{|l|l|l|l|}
\hline No & \multicolumn{1}{|c|}{$\begin{array}{c}\text { Use Case } \\
\text { Name }\end{array}$} & \multicolumn{1}{|c|}{ Description Actor } \\
\hline 1 & Login & $\begin{array}{l}\text { Use cases describe the activity of } \\
\text { entering a username and } \\
\text { password to access the system. }\end{array}$ & $\begin{array}{l}\text { Admin, super } \\
\text { admin, and user }\end{array}$ \\
\hline 2 & Logout & $\begin{array}{l}\text { Use cases describe the activities } \\
\text { out of the system. }\end{array}$ & $\begin{array}{l}\text { Admin, super } \\
\text { admin, and user }\end{array}$ \\
\hline 3 & File Upload & $\begin{array}{l}\text { Use cases describe student } \\
\text { activities to upload files }\end{array}$ & User \\
\hline 4 & $\begin{array}{l}\text { Profile } \\
\text { Mahasiswa }\end{array}$ & $\begin{array}{l}\text { Use cases describe student } \\
\text { activities entering student } \\
\text { profiles }\end{array}$ & User \\
\hline 5 & Upload & $\begin{array}{l}\text { Use cases describe student } \\
\text { activities to upload documents }\end{array}$ & User \\
\hline 6 & $\begin{array}{l}\text { Profile } \\
\text { Admin }\end{array}$ & $\begin{array}{l}\text { Use cases describe student } \\
\text { activities entering the admin } \\
\text { profile } \\
\text { Use cases describe admin } \\
\text { activities managing student data }\end{array}$ & $\begin{array}{l}\text { Admin, super } \\
\text { admin }\end{array}$ \\
\hline admin, super \\
\hline 8 & Gaht & $\begin{array}{l}\text { Gallery cases describe admin } \\
\text { activities in managing the gallery } \\
\text { menu }\end{array}$ & $\begin{array}{l}\text { Admin, super } \\
\text { admin }\end{array}$ \\
\hline
\end{tabular}


International Journal Of Science, Technology \& Management

\begin{tabular}{|c|c|c|c|}
\hline $\begin{array}{l}a \\
b\end{array}$ & Gallery & $\begin{array}{l}\text { Use cases describe user activities } \\
\text { to view information on the } \\
\text { gallery menu }\end{array}$ & user \\
\hline 10 & Verifikasi & $\begin{array}{l}\text { Use cases describe admin } \\
\text { activities to validate / verify } \\
\text { documents that have been } \\
\text { uploaded by the user }\end{array}$ & Admin \\
\hline P1 & Background & $\begin{array}{l}\text { Use cases describe admin } \\
\text { activities managing } \\
\text { background menu }\end{array}$ & $\begin{array}{l}\text { Admin, super } \\
\text { admin }\end{array}$ \\
\hline 12 & About & $\begin{array}{l}\text { Use cases describe admin } \\
\text { activities managing the about } \\
\text { menu about }\end{array}$ & $\begin{array}{l}\text { Admin, super } \\
\text { admin }\end{array}$ \\
\hline
\end{tabular}

System implementation is the application of information systems that have been designed by programmers to be tested on users. The implementation of the SIPESTA system was tested on students uploading documents, the admin validated by verifying the files uploaded by students, the admin made data withdrawals, and imports and the printing of reports or forms by users for students who had a trial in the 2019/2020 academic year. The trial will last until October 2020.

Figure 1 until figure 7 are some of the menus available at SIPESTA for users.

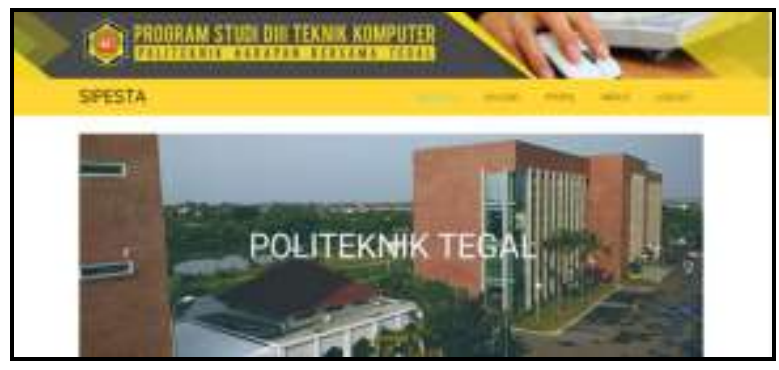

Fig. 1. The view of the main minister

At figure 1 can be seen the main menu display is an overview of the Polytechnic of Harapan Bersama Campus. In this main menu, images can be changed according to admin management. And users can only see information in the form of images or photos. 


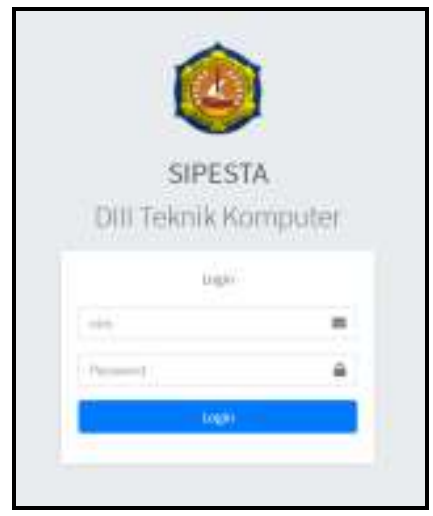

Fig. 2. the login menu

At figure 2 can be seen the login menu, the student's student ID will fill in the ID and password, where the initial password is the student ID and the user can change the password after entering the first time. If you have finished uploading or carrying out activities on SIPESTA, the user can log out.

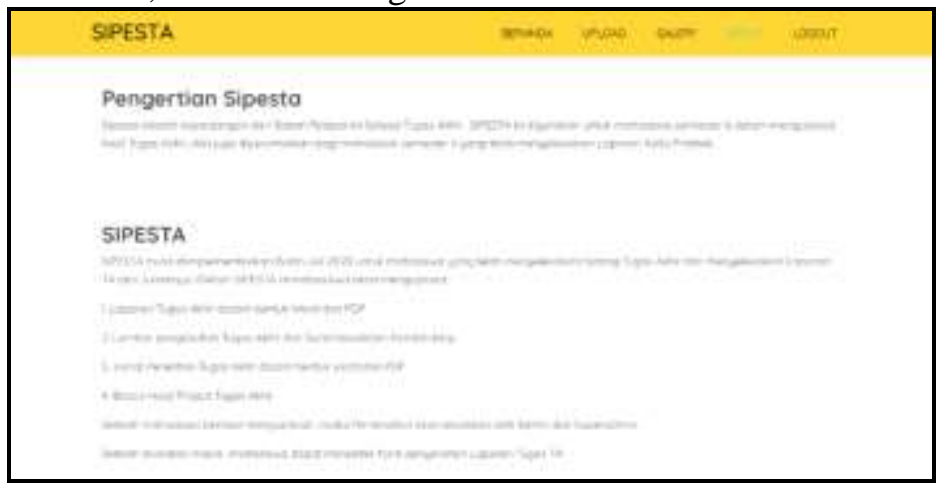

Fig. 3. The about menu

Figure 3 can be seen the about menu, this menu contains an explanation of SIPESTA and the flow of what SIPESTA functions for D3 Computer Engineering study program students.

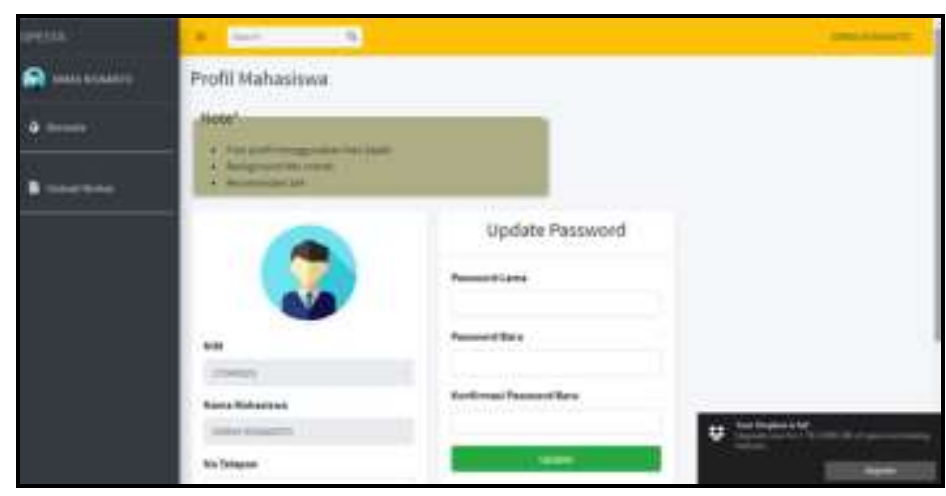

Fig. 4. The student's profile

Figure 4 can be seen in the student profile menu, the student must fill in a student profile because this data will be displayed on a report or form. This profile data 
contains Nim, student name, cellphone number, email address, and official photo. In this profile, data students will input before uploading documents. The student must fill the data according to the rules.

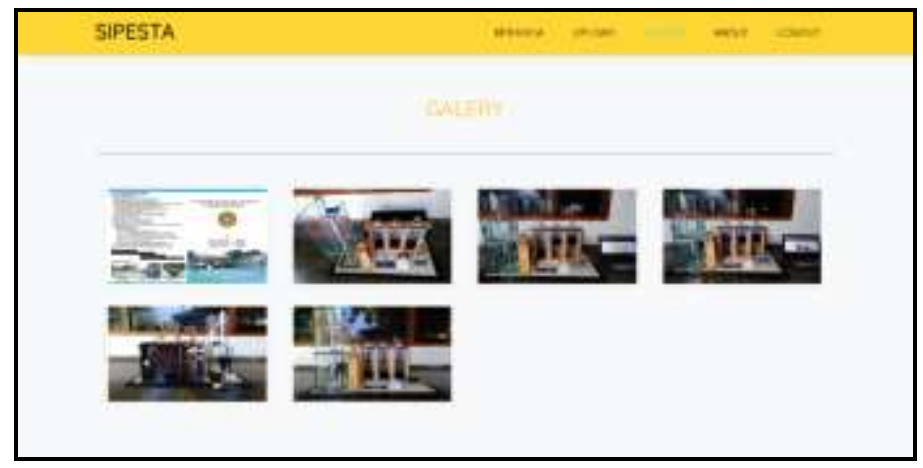

Fig. 5. The gallery's menu

Figure 5 can be seen in The Gallery menu. This menu can be seen from two actors, either user or student or admin or super admin. Users can only view information and photos or videos on the gallery menu, but the admin and super admin can manage the gallery menu, including creating, read, update, and delete.

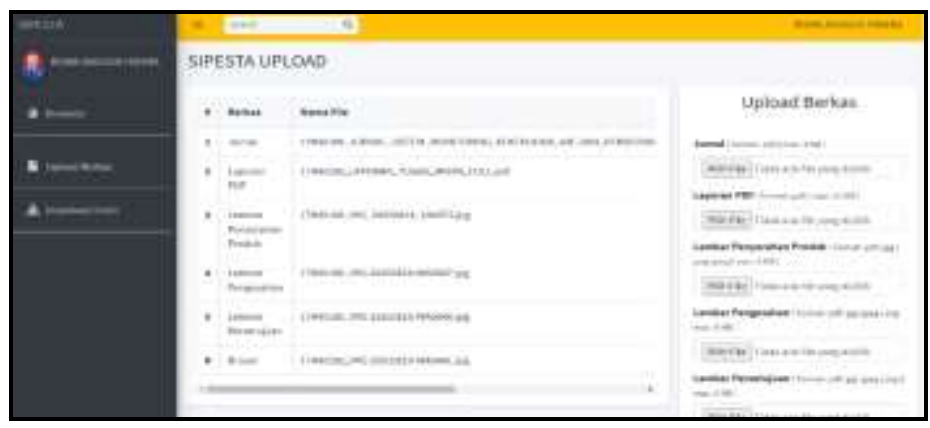

Fig. 6. The upload menu

At figure 6 can be seen the upload menu, menu will appear on the user, where the user or where the student will upload the file requested by the system with a minimum size of 10 bytes.

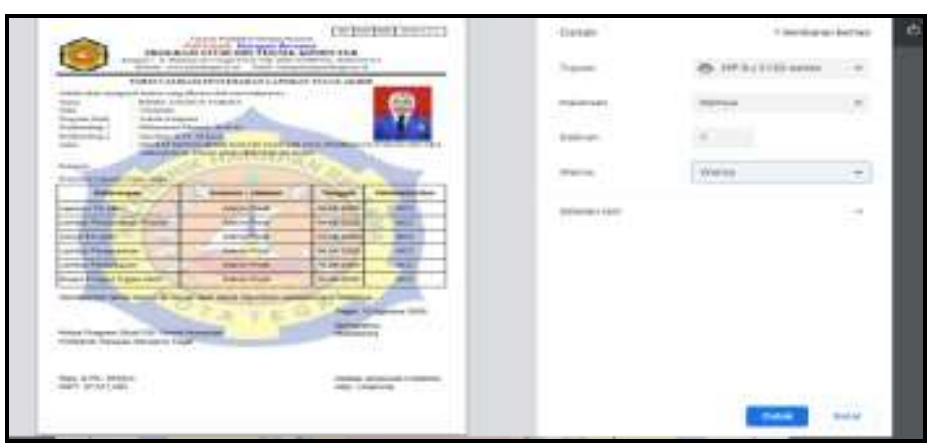

Fig. 7. The printing form menu 
Figure 7 can be seen in the Download and Print menu, this form contains the user can download the form for further administrative purposes.

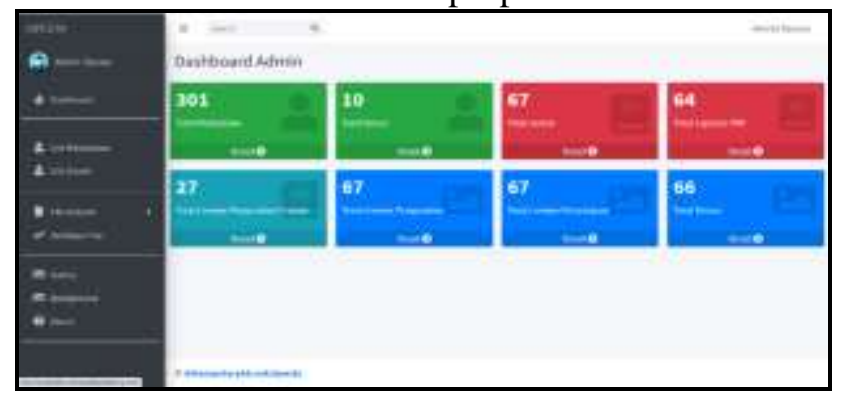

Fig. 8. Homepage menu

Figure 8 until figure 14 are some of the menus available at SIPESTA for admin or super admin.

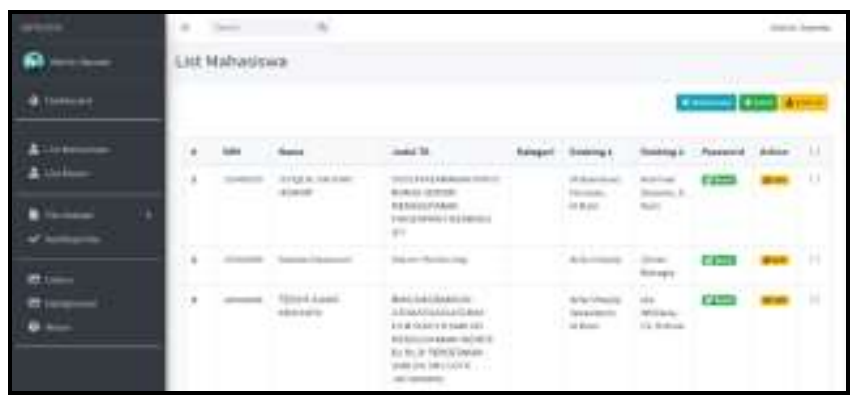

Fig. 9 the student list display

Figure 9 can be seen student list display, it shows the data files that have been uploaded by the user, where the admin and super admin can download if needed. All files are in pdf format. Here also the admin and supera dmin can input data one by one from the user data, or enter data by importing data in the form of an excel file.

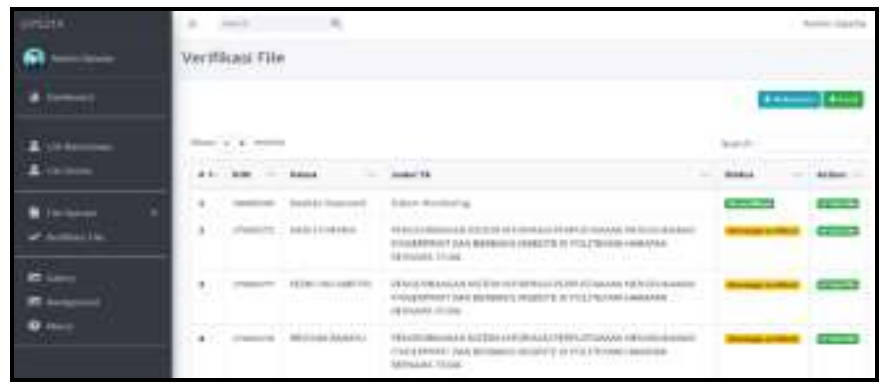

Fig. 10 the verification menu

Figure 10 can be seen the verification menu, where the admin or super admin can validate the uploaded documents, verify per user name and all the documents they have uploaded

\section{Testing Sipesta}

Testing on this information system is carried out with a black box as shown in table 4. All the parts of SIPESTA can be running properly and can be applied to 
International Journal Of Science, Technology \& Management

graduate in the academic year 2019/2020. Then next research will be carried out to development SIPESTA analysis from the user's side and Whitebox testing

Table 4. Black Box Testing

\begin{tabular}{|c|c|c|c|}
\hline No & $\begin{array}{l}\text { Part of the } \\
\text { system }\end{array}$ & Test item & $\begin{array}{c}\text { Black Box Test } \\
\text { Results }\end{array}$ \\
\hline 1 & $\begin{array}{l}\text { Login Menu } \\
\text { user/admin/super } \\
\text { admin }\end{array}$ & $\begin{array}{l}\text { user name and } \\
\text { password }\end{array}$ & Running properly \\
\hline 2 & $\begin{array}{l}\text { Profile menu } \\
\text { User/admin/super } \\
\text { admin }\end{array}$ & Profile & Running properly \\
\hline 3 & $\begin{array}{c}\text { Upload } \\
\text { document form }\end{array}$ & $\begin{array}{l}\text { Uploading Final } \\
\text { Project files } \\
\text { Upload the journal } \\
\text { Upload an attestation } \\
\text { sheet } \\
\text { Upload approval } \\
\text { sheet } \\
\text { Upload a brochure } \\
\text { Upload proof of tool } \\
\text { submission }\end{array}$ & Running properly \\
\hline 4 & Gallery Menu & $\begin{array}{l}\text { Add picture } \\
\text { Edit picture } \\
\text { Delete picture }\end{array}$ & Running properly \\
\hline 5 & About Menu & $\begin{array}{l}\text { Add picture } \\
\text { Edit picture } \\
\text { Delete picture }\end{array}$ & Running properly \\
\hline 6 & $\begin{array}{l}\text { Background } \\
\text { Menu }\end{array}$ & $\begin{array}{l}\text { Add picture } \\
\text { Edit picture } \\
\text { Delete picture }\end{array}$ & Running properly \\
\hline 7 & Student list form & $\begin{array}{l}\text { Searching student } \\
\text { data } \\
\text { Add student data } \\
\text { Edit student data } \\
\text { Delete student data }\end{array}$ & Running properly \\
\hline 8 & $\begin{array}{l}\text { Verification } \\
\text { Form }\end{array}$ & $\begin{array}{l}\text { Verify the uploaded } \\
\text { user file }\end{array}$ & Running properly \\
\hline 9 & $\begin{array}{l}\text { Download and } \\
\text { Print the Form }\end{array}$ & $\begin{array}{l}\text { download proof of } \\
\text { submission of the } \\
\text { Final Project file and } \\
\text { print the form }\end{array}$ & Running properly \\
\hline
\end{tabular}




\section{CONCLUSION}

This research was conducted from research problems in the D3 Computer Engineering study program, Harapan Bersama of Polytechnic, by considering several aspects. The research roadmap carried out this time is the implementation of the roadmap from the first year, wherein the following year it is a system analysis after 1 year of system trials and user responses using SIPESTA.

So far this research has been carried out on the design of this information system, several conclusions that have been produced. The existence of a database of student final project reports is good, where previously the database was only physically, but after this research is stored the database of student scientific papers that can be used at any time.

There is a reporting process Final project that is simpler and can be done more effectively, where the admins of the study program and students can interact via the website without having to meet face to face, this is very helpful in today's conditions where the Covit-19 pandemic that occurs requires reducing face-to-face interactions advance.

With the existence of SIPESTA, it can improve services in study programs and also between study programs and other parties, such as a library that will inventory all student work. But SIPESTA requires a large storage space because it will be the database for each generation, therefore maintenance is needed.

\section{ACKNOWLEDGMENTS}

The author is grateful to the Research and Community Service Institution Politeknik Harapan Bersama of Polytechnic, Deputy Academic Director, and the Chair of the D3 Computer Engineering Study Program and all of its staff.

\section{REFERENCES}

[1] A. Haqiqi Sulasmoro, I. Afriliana, I. Bukhari, P. DIII Teknik Komputer, and P. Harapan Bersama, “2 nd Seminar Nasional IPTEK Terapan (SENIT) 2017 Tegal-Indonesia," [Online]. Available: http://conference.poltektegal.ac.id/index.php/senit2017.

[2] P. Saputri, Z. Arifin, and Y. Yulianto, "Rancang Bangun Web Repositori Skripsi Mahasiswa Berbasis Oai-Pmh 2.0 Menggunakan Google App Engine (Studi Kasus : Program Studi Ilmu Komputer Universitas Mulawarman)," Inform. Mulawarman J. Ilm. Ilmu Komput., vol. 11, no. 1, p. 64, 2016, doi: 10.30872/jim.v11i1.206.

[3] A. Rachmat C., "Analisis Rancang Bangun Sistem Repositori Institusi Berbasis Metadata Dublin Core di UKDW Yogyakarta," J. Ultim. InfoSys, vol. 5, no. 2, pp. 65-74, 2014, doi: 10.31937/si.v5i2.267.

[4] S. A. Suwanto, "Manajemen Layanan Repository Perguruan Tinggi," Lentera Pustaka J. Kaji. Ilmu Perpustakaan, Inf. dan Kearsipan, vol. 3, no. 2, p. 165, 2017, doi: 10.14710/lenpust.v3i2.16740.

[5] S. Silarbi, B. Abderrahmane, and A. Benyettou, "Adaptive Network Based Fuzzy Inference System For Speech Recognition Through Subtractive Clustering," Int. J. Artif. Intell. Appl., vol. 5, no. 6, pp. 43-52, 2014, doi: 10.5121/ijaia.2014.5604.

[6] F. A. Ramadhan, "Analisis akses jurnal elektronik Perpustakaan Universitas Airlangga bagi mahasiswa Universitas Airlangga.,” J. Ilmu Inf. dan Perpust., vol. 1, no. 3, pp. 1-14, 2015. 